\title{
The Geographic Origins of Strategic Culture
}

\author{
Stephen B. Smith
}

Khazar University, Baku, Azerbaijan

\section{What is Strategic Culture?}

Before delving directly into the history of the subject, it might be helpful to give a definition so that one knows what is meant by the term strategic culture (a thorough description and assessment of the current debate over the definition of strategic culture is provided below). Scholars have failed to agree upon a definition of strategic culture. Colin Gray's definition, however, suits our purposes and will be used here: "[t]he persisting socially transmitted ideas, attitudes, traditions, habits of mind, and preferred methods that are more or less specific to a particular geographically based security community that has had a unique historical experience."1 This work argues that strategic culture does exist, meaning that polities differ in their approach to strategy and war. In order to understand further and explain the utility of strategic culture, this discussion addresses its history, sources, importance and the arguments of both its opponents and proponents.

Strategic culture is a derivative of political culture. Studies in political culture became fashionable during the 1960s with the publication of Gabriel Almond and Sidney Verba's The Civic Culture. ${ }^{2}$ One should think of political culture much like strategic culture, but in a broader sense. Political culture refers to the group's view of the proper role of the governing authority, while strategic culture refers to the group's view of how the governing authority should approach its security issues.

\footnotetext{
${ }^{1}$ Colin S. Gray, Modern Strategy (Oxford: Oxford University Press, 1999), p. 131.

${ }^{2}$ For two prominent works on political culture see, Gabriel Almond and Sidney Verba, The Civic Culture: Political Attitudes and Democracy in Five Nations (Boston: Little, Brown, 1965); and John S. Duffield, World Power Forsaken: Political Culture, International Institutions, and German Security Policy After Unification (Stanford, Calif.: Stanford University Press, 1999).
} 
Dissected even further, "national style" or "way of war" derives from strategic culture and refers to how a state wages war. ${ }^{1}$

\section{The History of Strategic Culture}

Jack Snyder introduced the term "strategic culture" during the 1970s in a report that argued that the Soviet approach to nuclear strategy differed greatly from that of the Americans. ${ }^{2}$ Though Snyder is credited with coining the term, the concept of strategic culture has existed for over two millennia. Sun Tzu and Thucydides both stressed in their classic works the importance of culture and its relationship with strategy. ${ }^{3}$ Using a similar approach to war and strategy Ken Booth, in 1979, reintroduced the concept of ethnocentrism, which suggests that "societies look at the world with their own group as the centre, they perceive and interpret other societies within their own frames of reference, and they invariably judge them inferior." While Booth credits W. G. Sumner with introducing the term in 1906, ${ }^{5}$ Richard E. Nisbett traces the word back to its origin in Ancient Greece. He claims, "The term resulted from the Greeks' recognition that their belief that their way of life was superior to that of the Persians might be based on mere prejudice. They decided it was not." Many of the themes in today's writings on culture and strategy resemble those in the works of both Snyder and Booth.

As should be obvious by now, the concepts of strategic culture and ethnocentrism are not novel. ${ }^{7}$ Throughout history one can find strategists who recognized the

\footnotetext{
${ }^{1}$ See, Colin McInnes, Hot War, Cold War: The British Army's Way in Warfare, 1945-95 (London: Brassey's, 1996), p. 3; Colin S. Gray, "British and American Strategic Cultures," in Democracies in Partnership: 400 Years of Transatlantic Engagement, The ACT/ODU Jamestown Symposium; 18-19 April, 2007, Norfolk, VA: HQ, Allied Command Transformation, 2008, pp. 123-150; Lawrence Sondhaus, Strategic Culture and Ways of War (London: Routledge, 2006), p. 1.

${ }^{2}$ Jack Snyder, The Soviet Strategic Culture: Implications for Limited Nuclear Operations, R-2154-AF (Santa Monica, Calif.: RAND, September 1977).

3 Jeffrey S. Lantis points this out in, "Strategic Culture: From Clausewitz to Constructivism," Strategic Insights, Vol. 4, Issue 10, (October 2005). Sun-tzu, The Art of War, Ralph D. Sawyer, trans., (Boulder, CO: Westview Press, 1994); Robert B. Strassler, ed., The Landmark Thucydides: A Comprehensive Guide to "The Peloponnesian War," Richard Crawley, trans., rev. edn., New York: Free Press, 1996.

${ }^{4}$ Ken Booth, Strategy and Ethnocentrism (New York : Holmes \& Meier, 1979), p. 13.

${ }^{5}$ Ibid., p. 15. Booth cites W. G. Sumner, Folkway (Boston: Ginn, 1906), p. 13.

${ }^{6}$ Richard E. Nisbett, The Geography of Thought: How Asians and Westerners Think Differently... and Why (New York, NY: Free Press, 2003), p. 4.

${ }^{7}$ To support his argument that the decline of geopolitical studies is more a result of academic trends than a natural adjustment to a major shift in international politics, Jakub Gry-
} 
differences in approaches to war and used such knowledge to their advantage. For example, Colin Gray points out that "[a]round 600 A.D., Byzantine Emperor Maurice devoted Book XI of his Strategikon to the 'characteristics and tactics of various peoples'; his purpose, he said, was 'to enable those who intend to wage war against these peoples [Persians, Scythians, Franks, Slavs] to prepare themselves properly. For all nations do not fight in a single formation or in the same way.","1 During the nineteenth century Carl von Clausewitz described war as having a subjective nature that is constantly evolving, and partially is shaped by the cultures of the belligerents. ${ }^{2}$ The general theories of war and strategy provided by Sun Tzu, Thucydides, and Clausewitz, serve as helpful guides for scholars interested in strategic culture and national ways of war.

The twentieth century witnessed numerous works on national ways of war, many of which were written by historians and drew little attention from political scientists. ${ }^{3}$ In 1932, Basil H. Liddell Hart wrote The British Way in Warfare and described Britain's traditional approach to warfare as an "indirect approach" that avoids direct assaults against the enemy's main force. He argued that the heavy British losses in the trenches on the Western Front during the First World War could have been avoided had it held to its traditional indirect approach. ${ }^{4}$ After the

giel points out that the history of academia is a history of the rise and decline of fashionable ideas. The same could be said of strategic culture. Grygiel quotes Tocqueville, who recognized this characteristic of institutions of higher learning when he said, "It is unbelievable how many systems of moral and politics have been successively found, forgotten, rediscovered, forgotten again, to reappear a little later, always charming and surprising the world as if they were new, and bearing witness, not to the fecundity of the human spirit, but to the ignorance of men." Jakub J. Grygiel, Great Powers and Geopolitical Change (Baltimore, MD: Johns Hopkins University Press, 2006), p. 180, fn 1, Originally quoted in David Yost, "Political Philosophy and the Theory of International Relations," International Affairs, Vol. 70, (April 1994), p. 265.

${ }^{1}$ Colin S. Gray, The Geopolitics of Super Power (Lexington, KY: The University Press of Kentucky, 1988) p. 136. Gray cites, George T. Dennis, trans., Maurice's Strategikon: Handbook of Byzantine Military Strategy (Philadelphia: University of Pennsylvania Press, 1984), p. 113.

2 Clausewitz, Carl von, On War, Michael Howard and Peter Paret, eds. and trans., (Princeton, NJ: Princeton University Press, 1976), pp. 585-594. See also Stephen Peter Rosen, "Military Effectiveness: Why Society Matters," International Security, Vol. 19, No. 4 (Spring, 1995) p. 27; and Lantis, "Strategic Culture."

${ }^{3}$ Sondhaus, Strategic Culture and Ways of War, p. 1.

${ }^{4}$ Basil H. Liddell Hart: The British Way in Warfare (London: Faber \& Faber, 1932); idem, The Strategy of the Indirect Approach (London: Faber \& Faber, 1941); For a differing perspective see Michael Howard, The Continental Commitment: The Dilemma of British Defence Policy in the Era of the Two World Wars (London: Maurice Temple Smith, 1972). For a challenge to the notion that Britain has a distinct way of warfare see David French, The British Way in Warfare, 1688-2000 (London: Unwin Hyman, 1990). 
Second World War Ruth Benedict-a student of Franz Boas, "father of American anthropology"- -studied Japanese culture in an effort to understand the aggression that produced such acts as the kamikaze attacks on the U.S. Navy. ${ }^{1}$

The latter half of the twentieth century saw three waves of works on national way of war hit strategic studies in the 1970s. First, in 1973, Russell Weigley presented his American Way of War, and set the standard for subsequent works on the subject. Weigley argued that the traditional American way of war is best characterized by its historical reliance on a strategy of annihilation. ${ }^{2}$ In the same year, Bernard Brodie's War and Politics provided us with a quote often cited by culturalists: "good strategy presumes good anthropology and sociology. Some of the greatest military blunders of all time have resulted from juvenile evaluations in this department." ${ }^{\prime 3}$ A year later, Frank A. Kierman Jr. and John K. Fairbank edited a volume entitled Chinese Ways in Warfare. ${ }^{4}$ A second wave came in the 1980s included works such as Edward S. Boylan "The Chinese Cultural Style of Warfare," Victor David Hanson's transnational work, The Western Way of War. ${ }^{7}$ The latest and perhaps most widespread wave of works on strategic culture followed Alastair Iain Johnston's Cultural Realism. ${ }^{8}$ Many of these waves brought different approaches to the study of war and culture and each author presented his or her own unique concept of strategic culture and its relevance to war and strategy.

\section{Sources of Strategic Culture}

The concept of strategic culture adopted here draws heavily from anthropology, social ecology and geopolitics. This work argues that differences in strategic styles are grounded in geography and shaped by history. In order to understand a

\footnotetext{
${ }^{1}$ Ruth Benedict, The Chrysanthemum and the Sword (Boston: Houghton Mifflin, 1946).

${ }^{2}$ Russell F. Weigley, The American Way of War: A History of United States Military Strategy and Policy (New York: Macmillan, 1973), p. xiv.

${ }^{3}$ Bernard Brodie, War and Politics (New York: Macmillan, 1973).

${ }^{4}$ Frank A. Kierman Jr., and John K. Fairbank, Chinese Ways in Warfare (Cambridge, Mass: 1974).

${ }^{5}$ Edward S. Boylan, "The Chinese Cultural Style of Warfare," Comparative Strategy, Vol. 3, No. 4, (1982), pp. 341-364.

${ }^{6}$ Colin S. Gray, Nuclear Strategy and National Style (London: Hamilton Press, 1986).

${ }^{7}$ Victor David Hanson, The Western Way of War: Infantry Battle in Classical Greece (New York: Knopf, 1989).

${ }^{8}$ Alastair Iain Johnston, Cultural Realism: Strategic Culture and Grand Strategy in Chinese History, (Princeton, New Jersey: Princeton University Press, 1995). For a list of works that followed Johnston, see Sondhaus, Strategic Culture and Ways of War, p. 2.
} 
particular strategic culture one needs to study in combination the geographic context, the historical context, and the political context of the polity under examination. Although geography and history work interdependently to shape strategic culture, for the sake of clarity it is best to discuss each separately and then in conjunction.

\section{Geography and Strategic Culture}

Geography provides the best starting point for examining the origins of different strategic cultures. ${ }^{1}$ People across the globe over time developed different ways of organizing themselves to adapt to their local environment. Because groups of people settled into territories with different geographical characteristics they adopted different ways of utilizing their territory to ensure survival and prosperity, which led to the development of distinct habits and attitudes about life. While some habits and especially attitudes within a polity will be ephemeral, responding to sudden and mild changes that effect the social environment, the habits and attitudes that are passed on from generation to generation with little change deserve the label "cultural." This is not to say that culture does not change, it changes constantly albeit usually very slowly. Causes for these changes may be consequences of geographic or climate changes, but are usually the result of interactions with neighboring nations (change in culture will be discussed at certain points throughout this work). After multiple interactions with neighbors, societies develop habits and attitudes about these interactions and interrelations, which eventually become cultural.

Geography as a source of strategic culture is not a novel idea. Hippocrates, "The Father of Medicine," suggested that the differences of character amongst people are explicable by their climate and geography. ${ }^{2}$ He is worth quoting at length:

\footnotetext{
${ }^{1}$ For a recent study that argues that geography is underappreciated by contemporary social scientists see Harm J.De Blij, Why Geography Matters: Three Challenges Facing America: Climate Change, the Rise of China, and Global Terrorism (New York: Oxford University Press, 2005). Oliver M. Lee points out that, "several scholars who have written about strategic culture in recent years were more specific in that they cited geography as a major source of a nation's strategic culture, but unfortunately most have stopped short of explaining why and how strategic culture is linked to geography. Lee, Oliver M., "The Geopolitics of America's Strategic Culture," Comparative Strategy, Vol. 27, No. 3, (May/Jun 2008), p. 272.

${ }^{2}$ Adda B. Bozeman, Politics and Culture in International History (Princeton, New Jersey: Princeton University Press, 1960), p. 75.
} 
And with regard to the pusillanimity and cowardice of the inhabitants, the principal reason the Asiatics are more unwarlike and of gentler disposition than the Europeans is, the nature of the seasons, which do not undergo any great changes either to heat or cold, or the like; for there is neither excitement of the understanding nor any strong change of the body whereby the temper might be ruffled and they be roused to inconsiderate emotion and passion, rather than living as they do always in the state... And you will find the Asiatics differing from one another, for some are better and others more dastardly; of these differences, as I stated before, the changes of the seasons are the cause. Thus it is with Asia. ${ }^{1}$

While his description of Asiatic peoples is dubious, and his insistence that geography and climate directly determine the nature of a society's temperament is arguable, Hippocrates' observation is noteworthy for its choice of sources of differing temperaments amongst polities. Herodotus, Hippocrates' contemporary, made similar observations, ${ }^{2}$ which have been expounded upon throughout history by scholars such as Bernhardus Varenius (1622-1650), Montesquieu (1689-1755), Immanuel Kant (1724-1804), and Fredrich Ratzel (1844-1904), to name a few.

The same unique ideas and beliefs that guided groups of people to develop distinct ways of organizing their labor to maximize their prosperity carried over into their efforts to secure the fruits of their labor from the threats posed by hostile neighbors who might not want to pay such a high price for provisions. Geography has a profound effect on the scale of a nation's interaction with other nations. Societies surrounded by rugged terrain or separated by great distances from other nations tend to have less interaction with foreign peoples than nations whose geography provides an easily accessible route (maritime or land) favorable for international commerce. For example, both the ancient Egyptians and the Chinese developed a strong sense of "us and them." Adda Bozeman suggests this attitude is a reflection of their geographies. Egypt was separated from the rest of Mesopotamia by the desert and the sea and had little contact with foreigners until the second millennium B.C. Similarly, China owes its isolation to the deserts and mountains in the north and west and the ocean to the east. Also, the great rivers of these ancient civilizations provided ample food, causing little need to trade and interact with foreigners. These geographic conditions heavily influenced their cultures and their self identity; both were highly ethnocentric and believed that they were respect-

\footnotetext{
${ }^{1}$ Hippocrates, On Airs, Waters and Places, part 16, (see also part 24), available online at http://classics.mit.edu/Hippocrates/airwatpl.mb.txt - Translated by Francis Adams.

${ }^{2}$ From Bozeman, Politics and Culture in International History, p. 75, fn 35, Bozeman cites Sarton, George, A History of Science, 2 Vols. Cambridge, 1952-1959. p. 369; and Baker, Ernest, Greek Political Theory, London, 1918, pp. 69ff.
} 
tively the "Empire of the Middle" and "the Middle Kingdom," around which all others revolved. ${ }^{1}$

Geography also serves as the cornerstone for defense orientation. In particular, the continental/maritime dichotomy provides a useful framework for further understanding of the subject. Carnes Lord explains that, "[t]he clearest contrast is that between island and continental powers, a contrast which affects not only a nation's force size and structure but also its fundamental strategic orientation." Concerning island powers he suggests, "the requirements of national defense have an intermittent rather than a continuous character, reliance tends to be placed on naval and militia forces rather than standing armies, and. . .commercial attitudes tend to shape national objectives and approaches to war." ${ }^{2}$ History is replete with examples to support this claim.

One of the more obvious cases is the island of Rhodes during the Hellenistic era. Rhodes was a maritime hub for commerce and used its navy to police the Mediterranean under the aegis of the Rhodian Sea Law. As a commercial power which hosted foreign merchants, its citizens were exposed to many other cultures. Also, the Rhodians were able to prosper from the commercial interactions and were not forced to rely on their own agriculture for food. Such an environment gave the Rhodians a greater degree of freedom to prosper and produce an almost natural governing order, mitigating the need for economic coordination under a highly centralized authoritative government. According to Bozeman, "The Rhodians became famous as traders, navigators, astronomers, jurists, and diplomats; they were respected as courageous defenders of national independence and human rights. But above all, they were known to stand for the freedom of the seas."”

The geographic explanation has much to offer strategists attempting to make sense of strategic history. Many of the great wars in history were fought between maritime and continental powers: Athens versus Sparta, Carthage versus Rome, Britain versus France/Germany, and the United States versus the Soviet Union. ${ }^{4}$ Continental and maritime powers each have certain advantages and disadvantages in war. In general, continental powers typically are able to utilize their interior lines to deliver mass at a precise point, while naval powers can use their mobility to launch coastal attacks at multiple points, thus stretching the forces of the opponent.

\footnotetext{
${ }^{1}$ Bozeman, Politics and Culture in International History, pp. 20, 26, 34.

2 Carnes Lord, "American Strategic Culture," Comparative Strategy, Vol. 5, (1985), pp. 272-273.

${ }^{3}$ Bozeman, Politics and Culture in International History, p. 108.

${ }^{4}$ See Colin S. Gray, The Leverage of Sea Power: The Strategic Advantage of Navies in War (Toronto: Free Press, 1992), passim.
} 
Also, continental powers usually fight on land where the defense tends to provide an advantage, whereas, maritime powers tend to wage naval warfare, in which the offense tends to have the advantage. Nevertheless, they tend to pay a higher price for retreat than do their sea power opponents and are less inclined to use limited force against major threats to their survival. ${ }^{1}$

Historically this continental-maritime interaction has prevented the rise of a hegemon on the Eurasian continent. ${ }^{2}$ This trend in strategic history is so strong that it serves as the basis for much geopolitical theory. Sir Halford Mackinder posited that if a continental power was ever able to obtain unimpeded access to the resources of the Eurasian interior - what he called "the heartland"- that it would be able to dominate the coastal areas, thus preventing any chance of an invasion by a maritime power whose purpose would be to restore the balance of power on the continent. Eventually, the continental hegemon would also become a naval power by utilizing its tremendous resources to build a navy capable of defeating that of any of the maritime powers. He famously stated:

Who rules East Europe controls the heartland:

Who rules the heartland commands the World-Island:

Who rules the World-Island commands the world. ${ }^{3}$

Mackinder believed that it was the proper role of the maritime powers to check any potential Eurasian hegemon. Maritime powers are not as likely to achieve world domination because of the difficultly they would have in conquering the heartland, where the defense tends to maintain the advantage.

Nevertheless, most of the successful great military powers have developed armed forces consisting of a combination of both land and naval elements. The reason for this is that a sea power with a strong naval capability and with a formidable land presence would generally be in a position to acquire more influence over both its

\footnotetext{
${ }^{1}$ Gray, Nuclear Strategy and National Style, p. 73.

${ }^{2}$ Christopher Layne explains that because continental powers lack strong geographic barriers that impede invasions they are inclined to seek security through attempts at hegemony by eliminating and then preventing the rise of potential rivals (see below). $\mathrm{He}$ argues that offshore/insular powers are more likely to adopt strategies that aim at the maintenance of a balance of power on the continent by preventing the rise of a hegemon, instead of seeking hegemony for themselves. Christopher Layne, The Peace of Illusions: American Grand Strategy from 1940 to the Present, (Ithaca: Cornell University Press, 2006), pp. 20-21; and idem, "From Preponderance to Offshore Balancing," in Michael E. Brown, Owen R. Cote, Jr., Sean M. Lynn-Jones and Steven E. Miller, America's Strategic Choices, International Security Readers, (Cambridge, Mass: MIT Press, 1997), p. 274.

${ }^{3}$ Halford J. Mackinder, Democratic Ideals and Reality: A Study in the Politics of Reconstruction [1919] (Suffolk: Penguin Books, 1944), p. 86.
} 
continental and maritime foes. Of course, this very much depends on how well its forces can operate jointly; the navy would need to be able to secure its strategic lines of communication (SLOCS) so that the land forces can be transported quickly and supplied sufficiently. ${ }^{1}$

This also holds true for a continental power, but in a slightly different manner. Naturally, continental powers are better situated to exploit the defensive. Their problem tends to be their inability to move armies to meet the land forces of the more mobile maritime powers. ${ }^{2}$ Thus, historically it takes less military effort for maritime powers to contain the expansion of the continental powers than it does for the continental powers to deny the maritime powers an entry point to the continent. If a continental power acquires access to a coastal port and is able to defend it successfully, it still faces a risk of a naval blockade preventing it from challenging naval powers on the open seas. ${ }^{3}$ Nonetheless, this does not mean that continental powers cannot exploit the maritime geographic dimension for strategic advantage. Because their strategic objectives tend to focus on defending or expanding their political influence on the continent, land powers do not need a navy capable of breaking through a blockade or acquiring command of the sea for the purpose of an amphibious invasion. With few exceptions-Hitler's "Operation Sealion" being one-land powers typically do not attempt to conquer island powers, and when they do so they risk possible invasion by neighboring states, particularly those allied with the island power. Continental powers do not need to command the sea

\footnotetext{
${ }^{1}$ The forces on land do not necessarily have to be a standing army or marine expeditionary force made up of one's own troops. Typically, for reasons of strategic culture, the land forces tend to be those of a continental ally or coalition.

${ }^{2}$ Mackinder feared that the land powers would capitalize on innovations in railway technology to offset the advantage that the sea powers have held for four hundred years. He suggested that "trans-continental railways are now transmuting the conditions of landpower, and nowhere can they have such effect as in the closed heartland of Euro-Asia, in vast areas of which neither timber nor accessible stone was available for road-making. Railways work the greater wonders in the steppe because they directly replace horse and camel mobility, the road stage of development having here been omitted." Halford J. Mackinder, "The Geographical Pivot of History," Geographical Journal, Vol. 23, No. 4, (April 1904), p.434.

${ }^{3}$ Mackinder was not alone in theorizing about such a possibility. During the Second World War, Nicholas J. Spykman warned about the negative geopolitical consequences for the West if the Soviet Union were given too much of the spoils of war. He suggested that the West secure the periphery (or what he called "the rimland") of Eurasia in order to prevent the geopolitical expansion of the Soviet Union. This was the basis of the containment strategy used by the United States during the Cold War. See Nicholas John Spykman, The Geography of the Peace (New York: Harcourt, Brace, 1944). See also Mackubin Thomas Owens, "In Defense of Classical Geopolitics," Naval War College Review, Vol. 52, no. 4, (Autumn 1999) pp. 59-76.
} 
to acquire a strategic advantage; they only need to deny the maritime power unimpeded access from the home country to the continent. A guerre de course strategy could be used to disrupt the SLOCs, making it difficult for the maritime power to bring manpower and supplies to the continent. This would cause the latter to divert its resources from maintaining and furthering its continental influence to focus on a buildup of naval forces to meet the challenge on the seas. ${ }^{1}$

To endorse the ideas of Mackinder and other geopolitical theorists who emphasize the role of the continental/maritime dichotomy throughout history does not necessarily make one a geographical determinist who rejects the important role of culture in strategy and war. ${ }^{2}$ It is geopolitics, nevertheless, that sets the stage for international relations. ${ }^{3}$ Geopolitical realities also help shape the form into which culture develops. This phenomenon is most obvious in the way in which states

${ }^{1}$ For more on this see Alfred Thayer Mahan, The Influence of Sea Power Upon History, 1660-1783 (Boston: Little, Brown, 1890). For more on the continental/maritime dichotomy see Colin S. Gray, War, Peace, and Victory: Strategy and Statecraft for the Next Century, (New York: Simon and Schuster, 1990), pp. 43-78.

${ }^{2}$ Some realists, including classical realists such as Hans Morgenthau, exaggerate the geographic focus of geopolitics to the point of accusations of determinism. See C. Dale Walton, Geopolitics and the Great Powers in the Twenty-first Century: Multipolarity and the Revolution in Strategic Perspective (London: Routledge, 2007), p. 18-23. Walton clarifies the relationship between geography and geopolitics, and takes critics such as Morgenthau to task for setting up straw targets in their arguments against classical geopolitics. For a somewhat different interpretation see Grygiel, Great Powers and Geopolitical Change, pp. 5-11. Grygiel credits Morgenthau (and others, particularly Nicholas Spykman) for rescuing geopolitics from Mackinder's geographically deterministic overtones by adding more of a human element to its study, thus prying open the natural sciences' grip on the subject, allowing it to be used by social scientists as well. However, reviewing Mackinder's work, particularly his Democratic Ideals and Reality, it is difficult to ignore the prescriptive theme which draws heavily from the history of man's attempts to utilize the natural geography of the territory that he inhabits for his own advantage. The purpose of much of Mackinder's work was to persuade the British Government that it should pay close attention to the balance of power on the continent because the technological innovations of the late nineteenth and early twentieth centuries were likely to result in a greater advantage for the great land powers - a shift from the previous four hundred years in which the sea powers maintained the advantage. It should also be pointed out that Mackinder argued that the "geographic pivot of history" is not static. One can only assume that geography itself could not cause the pivot to move, and therefore, it is the actions of human beings that create conditions which would allow for such movement. Raymond Aron maintains a similar view see, Raymond Aron, Peace and War (Garden City, NY: Doubleday, 1966), pp. 197-98.

${ }^{3}$ Grygiel explains that states do not always following the geopolitical path of least resistance, as "the knowledge of geopolitics indicates only the likely direction of a state's foreign policy." See Grygiel, Great Powers and Geopolitical Change, p. xii. Emphasis in the original. 
portion the disposition of their military forces. While treading dangerously near the banal it might be appropriate to state the obvious: continental powers tend to favor the army in defense allocation whereas island powers tend to favor the navy. While this fact in and of itself is more a response to geopolitical realities than to a cultural proclivity, culture influences how these states view the role of such forces. Geography alone cannot explain why certain maritime powers (or continental powers) devote large amounts of resources to the army (or the navy) at the expense of the navy (or the army). Yet, history is punctuated with examples, such as the British Expeditionary Force during the First World War and the German High Seas Fleet during the same war to name but two. ${ }^{1}$ Why is this so? Because the complexity of the human element that determines strategic objectives and oversees the organization of the military confounds simple mono-causal geopolitical explanations. One must therefore turn to history to make sense of geopolitics and its relationship with strategy. It is important to remember that while strategic culture is grounded in geopolitical reality, it is shaped by history.

\section{History and Strategic Culture}

Before beginning this discussion on how culture is shaped, it might be helpful to elaborate on the meaning of "culture." Raymond Williams describes culture as "a description of a particular way of life, which expresses certain meanings and values not only in art and learning but also in institutions and ordinary behaviour."2 Colin Gray suggests, "[c]ulture is about our identity and our loyalties. It is what we have learned about ourselves, our society and state, and the world, and it is about how we have learned to approach those vital maters."3 An empiricist approach, such as Gray's, has much to offer scholars interested in the relationship between culture and history. In reference to culture, people are their history, or to be more precise, people are what they perceive their history to be. Culture allows for identity, particularly in the context of being part of a community. It rewards those who think and behave within culturally established parameters, and punishes or shuns those that do not.

\footnotetext{
${ }^{1}$ See Peter Simkins, Geoffrey Jukes, and Michael Hickey, The First World War: The War to End All Wars, Essential histories special, 2. (Oxford, UK: Osprey, 2003) pp. 37-40, 275.

${ }^{2}$ Raymond Williams, "The Analysis of Culture," in John Storey (ed.), Cultural Theory and Popular

Culture: A Reader (Hemel Hempstead, UK: Prentice Hall, 1998), p. 48.

${ }^{3}$ Colin S. Gray, Another Bloody Century: Future Warfare (London: Weidenfeld \& Nicolson, 2005), p. 89. Emphasis in the original.
} 
As we have already established, geography provides the foundation for culture and social ecology provides explanations for its origin, but it is history that gives it its shape. When peoples from different cultures interact, they become familiar with certain beliefs and mindsets that did not mirror their own. After a number of interactions, beliefs and mindsets may be adjusted in order to maximize the probability that one's purpose for the interaction would be fulfilled. Over time patterns begin to form and with them the development of ideas concerning the likely success of certain approaches in dealings with neighbors. ${ }^{1}$ After these ideas are put into practice time and time again they became habitual and eventually cultural.

Such interactions surely produce a large degree of imitation, but what the different polities learn from one another would have been at least somewhat distorted by original ideas the polity held before the interactions took place. Also, the lessons learned from cultural exchanges, would be reshaped after being put into practice in one's home territory. One would, for example, expect that the nomads from the desert and the steppes, would view the purposes for the highly centralized authoritarian manner in which the hydraulic society of ancient China developed, through different lenses than those of the agrarian Chinese. ${ }^{2}$

\section{History, Geography and Strategic Culture}

G. P. Gooch reminds us that "geography is the mother of history." "Political geography, like physical geography, also sets the stage for cultural development and evolution. As mentioned earlier, island powers tend to be maritime-oriented, giving preference to the navy and relying on trade for material prosperity. Coastal polities will often share many cultural characteristics with both island and continental powers, because too great a preference for the army or the navy could open the door for an opponent to exert influence over the state. Nonetheless, not all continental powers are created equal. Insular continental powers such as China - which is surrounded by oceans on its eastern flank, mountains on the west, and a desert on the north-will not experience a continual major threat to its

\footnotetext{
${ }^{1}$ For more on history and learning in regards to military behavior see John Shy, "The American Military Experience: History and Learning," Journal of Interdisciplinary History, Vol. 1, No. 2, (Winter, 1971), pp. 208-210.

${ }^{2}$ See Karl A. Wittfogel, Oriental Despotism: A Comparative Study of Total Power (New Haven and London: Yale University Press, 1957)

${ }^{3}$ G.P.Gooch, "History as a Training for Citizenship," Contemporary Review, Vol. 137, (1930).
} 
survival by one of its neighbors. ${ }^{1}$ The only natural barriers that non-insular continental powers such as Russia have for protection is sheer distance from hostile neighbors. Thus, they rarely have a respite from major security threats. ${ }^{2}$

Again, these geographic realities do not determine culture per se, but they set the stage, allowing history to shape culture. Actually, it is history, not geography, that provides empirical evidence for the relevance of geopolitical theory. Through a large portion of its history, Russia has faced major external threats to its security. ${ }^{3}$ Next door, however, the Chinese have rarely faced a major external threat to their way of life. ${ }^{4}$ These influences tend to have a major effect on a polity's style of war and strategy. For example, Bozeman explains that throughout most of its history the Byzantine empire was geographically surrounded by multiple states powerful enough to pose a serious threat to its survival. She suggests that Byzantium adopted a strategic style that allowed for great flexibility and provided feasible options short of war not because it disdained organized violence, but because it wanted to avoid a multi-front assault on its homeland. ${ }^{5}$

While some polities might have similar geographies, the fluidity of the human element that permeates history ensures that each polity will have a unique way of viewing the world and its rightful place in that world. Each and every security community's strategic culture will be sui generis because no two polities have identical histories. Also, some are more demographically and economically blessed than others. Although this is mostly caused by geography, it is also a function of how territorial resources are managed. Some states historically have had powerful neighbors while others have not. At times relations with neighbors will be better than others. The geographic, historic, and political contexts help explain a polity's culture and how it slowly changes.

\footnotetext{
${ }^{1}$ India, sheltered by the Arabian Sea on the west, the Bay of Bengal on the East, and the Himalayas on the North will share a similar geostrategic orientation with China.

2 See John Glenn, "Russia," in John Glenn, Darryl Howlett, and Stuart Poore, (eds.) Neorealism Versus Strategic Culture (Aldershot: Ashgate, 2004), p. 173. Glenn opens his section on the sources of Russia's strategic culture with, "Two of the main sources of Russia's strategic culture are geography and history."

${ }^{3}$ A state attempting to conquer Russia would have to have an army large enough, with sufficient provisions and logistic lines to traverse the steppes before reaching the major cities. An army capable of such a feat would surely pose a major threat.

${ }^{4}$ While it is true that the Mongols at times have posed a major military threat and have even successfully taken control of the government, it was the invaders who were assimilated by their hosts, not the other way around.

${ }^{5}$ Bozeman, Politics and Culture in International History, pp. 310-311.
} 


\title{
Summary The Geographic Origins of Strategic Culture
}

\author{
Stephen B. Smith \\ Khazar University, Baku, Azerbaijan
}

Strategic culture is a concept that characterizes the way a security community thinks about the use of force or the threat of the use of force. It is constantly evolving, but only changes slowly as it is tethered to geography and history. Strategic culture allows the realists to hone his or her skills even more precisely than material variables allow for as beliefs and habits of mind are important variables in decision making at the top levels, but are difficult to quantify. For practitioners of strategy the concept of strategic culture is a helpful tool in understanding what kinds of forces an opponent will deploy and how they will be used in war. Before, however, we can use strategic culture to help us prepare strategies we must first develop a deep understanding of where it comes from then we should be able to understand better our opponents and eventually perhaps even ourselves.

Key words: Strategic culture, war strategy, security community 